\title{
The Influence of Principal Leadership and Teacher Working Group Activities on Teacher Performance at State of Elementary School Cluster III District Kayuagung
}

\author{
Verralesmana ${ }^{1 *}$, Bukman $\operatorname{Lian}^{2}$, Mulyadi $^{2}$
}

\author{
${ }^{I} S D$ Negeri 8 Kayuagung \\ ${ }^{2}$ Universitas PGRI Palembang \\ *Corresponding author. Email:verralesmana29@gmail.com
}

\begin{abstract}
This study aims to analyze the influence of leadership of the principal and the teacher working group on the teacher performance of the elementary school Gugus 3, Kayuagung District. This type of research is descriptive. Samples in the study were 51 respondents with data collection techniques in the form of questionnaires. Data analysis techniques used 1) descriptive quantitative analysis techniques; and 2) multiple regression. The results showed that:1) there is a significant influence of the Principal Leadership on teacher performance, 2) there is significant effect of the Teacher Work Group on teacher performance,3)there is a significant influence between the Principal Leadership and the Work Group teachers on teacher performance.
\end{abstract}

Keywords: Principal Leadership, Working Group, Teacher Performance

\section{INTRODUCTION}

The principal is an educational component that has a fairly high role in improving the quality of education [1]Observing this, it is fitting for a school principal to put forward dynamic leadership[2] Good self-adjustment will have an impact on optimizing the activities carried out by teachers in the work group.

Based on the experiences and observations of researchers at State Elementary Schools (SD) which are members of Cluster 3 Kayuagung, the implementation of the KKG has not been optimal. The activities of the teacher working group held tend to share documents not knowledge. So that the process of transformation of knowledge among teachers has not proceeded properly.

It was revealed from the direct findings of the researchers during the preliminary study. Information given by the principal regarding the process that occurs in the teacher working group makes teachers more comfortable duplicate documents rather than properly understanding them.how to compile the document, including learning tools.

Therefore, a firm attitude in the leadership of the principal to carry out his authority needs to be optimized. Learning devices submitted by the teacher for administrative processes in schools are recognized as the result of sharing documents, so this indicates that the teacher's competence to understand the document itself is not optimal. This means, it is indicated that teacher performance is not so good. The low performance of teachers in schools is influenced by various factors including competence, work motivation, work discipline, job satisfaction, the organization where teachers teach, the leadership of the school principal, as well as the existence of government policies on education[3][4].

According to Isdaryanti et al teacher performance includes the ability to prepare lesson plans; ability to carry out learning; the ability to carry out interpersonal relationships; ability to carry out assessment of learning outcomes; ability to carry out enrichment programs; and the ability to implement remedial programs [5] The teacher working group is a collection of activities carried out by the teacher community in a cluster that has relatively the same characteristics of the task field, usually consisting of groups of class teachers, subject teachers, and / or guidance and counseling teachers [6] Hidayah \& Sugiarto also explained that the teacher working group is a forum for professional guidance that can be used to carry out various demonstrations, attractions and simulations in learning[7]

Several studies related to principal leadership, teacher working group activity and teacher performance were examined by Winiangsih entitle the influence of school principal leadership and teacher activeness in participating in MGMP on teacher performance[8] This study yields information that there is an effect of principal leadership and teacher activeness in participating in subject teacher deliberations on the performance of state high school economics or accounting teachers in Kendal Regency either partially or simultaneously. In addition, Purwana, A. Ahmad, and A. Saptono conducted research that focused on the influence of principal leadership and teacher commitment to teacher professional performance[9] 
The result of his research is that the professional performance of teachers is positively influenced by the leadership of the principal. That is, the better the leadership of a school principal, the more optimal the professional performance of the teacher will be. The results of the research conducted by Hallingker \& Walker, conducted a study on the Exploring the mediating effects of trust on principal leadership and teacher professional learning[10] The result of his research is the professional performance of teachers is positively influenced by the leadership of the principal. That is, the better the leadership of a school principal, the more optimal the professional performance of the teacher will be. The results of the research conducted by Rahmayani, Arafat \& Mulyadion the Effect of Principal Leadership Behavior and Community Participation on Education Implementation at SMP Negeri 11 Prabumulih[11] The result of his research is that good leadership by the principal is able to support the implementation of education well, meaning that the leadership of the principal has a positive and significant impact on education delivery. Damayanti, Arafat \& Eddy (2020) with the research title The Effect of Principal Leadership and Work Motivation on Teacher Performance[12] The results of this study found that good principal leadership produced good teacher performance as well. This means that there is a significant influence between the principal's leadership on teacher performance.

\section{METHODS}

\subsection{Research Method}

This research method used descriptive qualitative research methods. According to Kozleskithe descriptive method is a method used to search for the elements, characteristics, and properties of a phenomenon.[13] This method begins with collecting data, analyzing data and interpreting it. Data collection used a questionnaire and documentation, then tabulated to be tested through the classical assumption test.

\subsection{Subject of Research}

The subjects were all teachers and principals of public schools who were members of cluster 3, Kayuagung District

Table 1. Research

\begin{tabular}{|c|l|c|c|}
\hline No & \multicolumn{1}{|c|}{ Description } & SampleTrial & $\begin{array}{c}\text { Sample Main } \\
\text { sample }\end{array}$ \\
\hline 1 & SDN 5 Kayuagung & - & 7 \\
\hline 2 & SDN 8 Kayuagung & - & 10 \\
\hline 3 & SDN 14 Kayuagung & - & 34 \\
\hline 4 & SDN 15 Kayuagung & 14 & - \\
\hline 5 & SDN 18 Kayuagung & 7 & - \\
\hline & Total & 21 & 51 \\
\hline
\end{tabular}

Based on the table above, it is clear that the sample in this study was 72 people spread across several schools. It is described that the sample is used by the researcher to test the instrument as many as 21 people, meaning that there are 51 people who are the main sample

\subsection{Technique of Analyzing Data}

Classical assumption test used data normality testing and data heteroscedasticity. Normality testing is through the Kolmogorov-Smirnov (KS) test through the SPSS program. Heteroscedasticity test is a test that assesses whether there is an inequality of variants of the residuals for all observations in the linear regression model. Testing the research hypothesis used parametric statistical analysis through the " $t$ " test for partial testing and the "F" test for simultaneous hypothesis

The formula testing for simple regression testing use test " $t$ "

$$
t_{h i t}=\frac{b}{S b}
$$

The formula testing regression test used the "F"

$$
F_{\text {count }}=\frac{J K T c / d b}{J K E / d b}
$$

To the coefficient of determination (R2)

the coefficient of determination is a test of the amount of influence of independent variables on the dependent variable

If the data were normally distributed, then the test can be done with parametric statistical analysis " $\mathrm{t}$ " test. The partial test is carried out with a significance level of $\sigma=$ 0.05 .

Accept $\mathrm{H}_{\mathrm{o}}$ : if the value of $\mathrm{t}_{\text {arithmetic }} \leq \mathrm{t}_{\text {table }}$ reject $\mathrm{H}_{\mathrm{a}}$ Reject $\mathrm{H}_{\mathrm{o}}$ if the value of $\mathrm{f}_{\mathrm{t}} \mathrm{t}_{\text {table }}$ thank $\mathrm{H}_{\mathrm{a}}$

If the data were normally distributed, then testing can be done by statistical analysis parametric test " $F$ " to test multiple regression simultaneous. Simultaneous testing is carried out with a significance level of $\sigma=0.05$.

\section{Accept $\mathrm{H}_{\mathrm{o}}$ if $\mathrm{F}_{\text {count }} \leq \mathrm{F}_{\text {table }}$ reject $\mathrm{H}_{\mathrm{a}}$}

RejectH $\mathrm{H}_{\mathrm{o}}$ if $\mathrm{F}_{\text {count }>} \mathrm{F}_{\text {table }}$ thanks $\mathrm{H}_{\mathrm{a}}$

\section{RESULTS AND DISCUSSION}

In the course of research, researchers distributed questionnaires to determine the leadership of the principal and teacher working group activities which became the research sample. Then the researchers collected again for data grouping to make it easier for researchers to carry out the analysis. The grouped questionnaire was then recapitulated by the researcher for further analysis.

Research data obtained through a research questionnaire, then tabulated to be tested through classical assumption test. The classical assumption test used is data normality testing and data heteroscedasticity. The prerequisite test results state that the data is normally distributed, and there are no symptoms of heteroscedasticity. Thus, research hypothesis testing can be carried out using parametric statistical analysis through the " $\mathrm{t}$ " test for partial testing and the "F" test for simultaneous hypothesis testing. Testing of the data obtained is continuously carried out by researchers through the help of the SPSS program.

In principle, this study uses three main variables. studied, with 2 (two) independent variables and 1 (one) 
dependent variable. For this reason, each variable is described regarding the data obtained through the research that has been carried out. For more details, see the following table and figure.

Table 2 Variable Frequency Distribution PrincipalLeadership

\begin{tabular}{|c|c|c|c|c|c|}
\hline \multicolumn{2}{|c|}{} & $\begin{array}{c}\text { frequ } \\
\text { ency }\end{array}$ & Percent & Valid Percent & $\begin{array}{c}\text { Cumu } \\
\text { Percentlativ } \\
\text { e }\end{array}$ \\
\hline Va & 74.55 & 1 & 2.0 & 2.0 & 2.0 \\
& 75.45 & 4 & 7.8 & 7.8 & 9.8 \\
& 76.36 & 2 & 3.9 & 3.9 & 13.7 \\
& 77.27 & 2 & 3.9 & 3.9 & 17.6 \\
& 78.18 & 8 & 15.7 & 15.7 & 33.3 \\
& 79.09 & 8 & 15.7 & 15.7 & 49.0 \\
& 80,00 & 6 & 11.8 & 11.8 & 60.8 \\
& 80.91 & 2 & 3.9 & 3.9 & 64.7 \\
& 81.82 & 1 & 2.0 & 2.0 & 66.7 \\
& 82.73 & 7 & 13.7 & 13.7 & 80,4 \\
& 83.64 & 5 & 9.8 & 9.8 & 90.2 \\
& 84.55 & 2 & 3.9 & 3.9 & 94.1 \\
& 85.45 & 2 & 3.9 & 3.9 & 98.0 \\
& 86.36 & 1 & 2.0 & 2.0 & 100.0 \\
& Total & 51 & 100.0 & 100.0 & \\
\hline
\end{tabular}

Source: processed data (October, 2020)

In the table above, the achievement of the final score of research respondents regarding principal leadership is found at 78.18 and 79.09 values. Each of these values was achieved by as many as 8 (eight) research respondents. This states that the leadership of the principal is very good, meaning that most respondents stated that the leadership of the principal was categorized as good.

When classified according to the sample group, the highest final average score was achieved by state of elementary school (SDN) 8 Kayuagung of was 82.64. The lowest final average value is found in state of elementary school 14 Kayuagung amounting to 79.41. If an in-depth analysis is carried out, that the difference between the highest and lowest values is not so wide, namely, 3.23. This value is not declared significant because between the highest and lowest scores are still included in the same category, namely the leadership of the principal is good.

If the classification of the final average score achievement is carried out in each school that is the research sample related to the leadership of the principal, it can be seen in the following table.

Table 3. Comparison of Final Value of Principal Leadership Variables

\begin{tabular}{|c|l|c|}
\hline No & \multicolumn{1}{|c|}{ Information } & Principal Leadership \\
\hline 1 & SDN 5 Kayuagung & 80.39 \\
\hline 2 & SDN 8 Kayuagung & 82.64 \\
\hline 3 & SDN 14 Kayuagung & 79.41 \\
\hline
\end{tabular}

Source: processed data (October, 2020)

For teacher work group variables As the second independent variable $\left(\mathrm{X}_{2}\right)$ in this study, a description of the frequency distribution of the final value according to the perception of the research sample can be seen in the following table.
Table 4. Variable Frequency Distribution of Teacher Working Group

\begin{tabular}{|c|c|c|c|c|c|}
\hline \multicolumn{2}{|c|}{} & $\begin{array}{c}\text { Fre } \\
\text { quency }\end{array}$ & Percent & $\begin{array}{c}\text { Valid } \\
\text { Percent }\end{array}$ & $\begin{array}{c}\text { Cumulative } \\
\text { Percent }\end{array}$ \\
\hline Va & 75.45 & 2 & 3,9 & 3,9 & 3,9 \\
& 76,36 & 2 & 3,9 & 3,9 & 7,8 \\
& 77,27 & 3 & 5.9 & 5.9 & 13.7 \\
& 78.18 & 7 & 13.7 & 13.7 & 27.5 \\
& 79.09 & 11 & 21.6 & 21.6 & 49.0 \\
& 80.00 & 6 & 11.8 & 11.8 & 60.8 \\
& 80, & & & & \\
& & & 9147.87 .8 & & \\
& & & 68.681 .823 & & \\
& & & 5.9 & & 94.1 \\
& 84.55 & 4 & 7.8 & 7.8 & 96.1 \\
& 85.45 & 1 & 2.0 & 2.0 & 100.0 \\
& 86.36 & 2 & 3.9 & 3.9 & \\
& Total & 51 & 100.0 & 100.0 & \\
\hline
\end{tabular}

Source: data processed (October, 2020)

In the table above, what is clear about the achievement of the final score of research respondents regarding teacher work group activities is a value of 79.09. This value was achieved by 11 (eleven) research respondents. When examined in more depth about the information displayed in the table, it appears that only 3 (three) people stated that the teacher's working group activities were very good. This means that most of the respondents stated that the teacher work group activities were in good category.

When classifying the final average score achievement at each school that was the research sample related to the teacher working group activities, it can be seen in the following table.

Table 5. Comparison of Final Values of Teacher Working Group Variables

\begin{tabular}{|c|l|c|}
\hline No & \multicolumn{1}{|c|}{ Information } & $\begin{array}{c}\text { Teacher Working } \\
\text { Group }\end{array}$ \\
\hline 1 & SDN 5 Kayuagung & 80.39 \\
\hline 2 & SDN 8 Kayuagung & 81.82 \\
\hline 3 & SDN 14 Kayuagung & 79.92 \\
\hline
\end{tabular}

Source: processed data (October, 2020

\section{Hypothesis Testing}

Hypothesis 1 intended in this study is a test for the first hypothesis, which is as follows:

$\mathrm{H}_{1}$ : $\mathrm{H}_{0}$ : It is suspected that there is no influence of the principal's leadership on the performance of teachers in SD Negeri cluster 3, Kayuagung District.

$\mathrm{H}_{\mathrm{a}}$ : It is suspected that there is an influence of the principal's leadership on the performance of SD Negeriteachers group 3 District of Kayuagung. 
Table 6. Results of Testing Hypotheses 1 "t-test" Coefficients

\begin{tabular}{|c|c|c|c|c|c|}
\hline \multirow[b]{2}{*}{ model } & \multicolumn{2}{|c|}{$\begin{array}{c}\text { unstandardized } \\
\text { Coefficients }\end{array}$} & \multirow{2}{*}{$\begin{array}{c}\begin{array}{c}\text { Standardize } \\
\mathrm{d} \\
\text { Coefficient } \\
\mathrm{s}\end{array} \\
\text { Beta }\end{array}$} & \multirow[b]{2}{*}{$\mathrm{t}$} & \multirow[b]{2}{*}{ Sig. } \\
\hline & $\mathrm{B}$ & Std. Error & & & \\
\hline (Constant) & & 8.549 & & 4.534 & $\begin{array}{r}38.764 \\
, 000,\end{array}$ \\
\hline $\begin{array}{l}\text { Principal } \\
\text { Leadership }\end{array}$ & & 529,107 & 579 & 4.967 &, 000 \\
\hline
\end{tabular}

Source: processed data (October, 2020)

The table above is the result of partial hypothesis testing, namely testing $X_{1}$ against $Y$. Based on the results of the tests that have been done, it is known that the $t$ value for the principal's leadership variable is $4,967>t_{\text {table, }}$ namely 2.009, which means that the alternative hypothesis $\left(\mathrm{H}_{\mathrm{a}}\right)$ for testing hypothesis 1 is accepted. Therefore, it is stated that the principal's leadership has a positive and significant effect on the performance of public SD teachers in cluster 3 of Kayuagung District. Other proof can also be done by looking at the significance value which is $0.000<0.05$ which means that the alternative hypothesis $\left(\mathrm{H}_{\mathrm{a}}\right)$ for $\mathrm{H}_{1}$ accepted.

\section{Hypothesis 2 Testing Hypothesis 2}

The testing in this study is intended to test the following hypotheses:

$\mathrm{H}_{2}$ : $\mathrm{H}_{0}$ : It is suspected that there is no effect of teacher work group activities on the performance of teachers at state of elementary school cluster3Kecamatan Kayuagung.

$\mathrm{H}_{\mathrm{a}}$ : It is suspected that there is an effect of teacher working group activities on the performance of teachers at state of elementary school cluster 3, Kayuagung District.

The results obtained from testing the above hypothesis are as follows:

Table 7. Hypothesis Testing Results 2 "t test" Coefficients

\begin{tabular}{|c|c|c|c|c|c|}
\hline \multirow[b]{2}{*}{ Model } & \multicolumn{2}{|c|}{$\begin{array}{c}\text { Unstandardized } \\
\text { Coefficients }\end{array}$} & \multirow{2}{*}{$\begin{array}{c}\begin{array}{c}\text { Standardi } \\
\text { zed } \\
\text { Coefficie } \\
\text { nts }\end{array} \\
\text { Beta }\end{array}$} & \multirow[b]{2}{*}{$\mathrm{t}$} & \multirow[b]{2}{*}{ Sig. } \\
\hline & $\mathrm{B}$ & Std. Error & & & \\
\hline ] (Constant) & & 9.848 & & 4.344 & $\begin{array}{r}42.779,00 \\
0,\end{array}$ \\
\hline $\begin{array}{l}\text { Teacher Working } \\
\text { Group }\end{array}$ & & 478,122 & 487 & 3.903, & 000 \\
\hline
\end{tabular}

a. Dependent Variable: Teacher Performance

Source: processed data (October, 2020)

In the " $\mathrm{t}$ " contained in the table above is known to a value of 3.903 which is the value $e_{t}$ for the variable activities of working groups of teachers. From this value, it is interpreted at the tvalue table $_{\text {which }}$ is equal to 2.009, which means $t_{\text {count }}>t_{\text {table }} ; 3,903>2,009$. Based on this, it is concluded that the alternative hypothesis is accepted, which means that teacher work group activities have a positive and significant effect on teacher performance in SD Negeri in cluster 3, Kayuagung District.

\section{Hypothesis 3}

Testing This test is a joint test, namely the independent variables are jointly tested on the dependent variable. The third hypothesis in this study is as follows:

$\mathrm{H}_{3}: \mathrm{H}_{0}$ : It is suspected that there is no influence of the leadership of the principal and the activities of the teacher working group together on the performance of teachers at state of elementary school cluster 3, Kayuagung District.

$\mathrm{H}_{\mathrm{a}}$ : It is suspected that there is an influence of the leadership of the principal and the activities of the teacher working group collectively on the performance of teachers in state of elementary school cluster 3, Kayuagung District.

The results obtained from these tests can be seen in the following table.

Table 8. Results of Hypothesis 3 Testing "F test" ANOVA $^{\mathrm{a}}$

\begin{tabular}{|l|r|r|r|r|r|}
\hline Model & \multicolumn{1}{|c|}{$\begin{array}{c}\text { Sum of } \\
\text { Squares }\end{array}$} & \multicolumn{1}{c|}{ df } & \multicolumn{1}{c|}{$\begin{array}{c}\text { Mean } \\
\text { Square }\end{array}$} & \multicolumn{1}{c|}{ F } & Sig. \\
\hline $\begin{array}{l}\text { 1 Regressio } \\
\text { n }\end{array}$ & 128.118, & 2 & 64.059 & 12.383 & $000^{\mathrm{b}}$ \\
$\quad$ Residual & 248.311 & 48 & 5.173 & & \\
$\quad$ Total & 376.429 & 50 & & & \\
\hline
\end{tabular}

a. Dependent Variable: Teacher Performance

b. Predictors: (Constant), Principal Leadership, Teacher Working Group

Source: processed data (October, 2020)

In the table above, to be precise in column $\mathrm{F}$ there is a value of $12.383>\mathrm{F}_{\text {Table }}$ of 3.191 which means there is a positive and significant influence on head leadership schools and teacher working group activities jointly on the performance of teachers in state of elementary school in cluster 3, Kayuagung District.

\section{The Influence on Performance Leadership School head teacher}

hypothesis test obtained value for $_{\mathrm{t}}$ the variable of school leadership for $4.967>\mathrm{t}_{\text {table }}$ is 2.009 , which means that the alternative hypothesis $\left(\mathrm{H}_{\mathrm{a}}\right)$ to test the hypothesis 1 is accepted. Therefore, it is stated that the leadership of the principal has a positive and significant effect on the performance of public state of elementary school teachers in cluster 3 of Kayuagung District. Other proof can also be done by looking at the significance value, which is $0.000<0.05$, which means that the alternative hypothesis $\left(\mathrm{H}_{\mathrm{a}}\right)$ for $\mathrm{H}_{1}$ is accepted.

The correlation coefficient or the magnitude of the relationship between principal leadership and teacher performance is $57.9 \%$, and is included in the category of a strong enough relationship. The determinant coefficient or the magnitude of the influence of the principal's leadership variable on the performance of teachers in state of elementary school in cluster 3, Kayuagung District, is $33.5 \%$ which means it has a low influence.

The results of this study support several previous studies, research by Sauri, Widyasari\&Sesritapada in 
2018. as well as research by M. Nova, Rohana, and M. Kristiawan in 2019 [14][15] Some of these studies clearly state that the leadership of a school principal is able to have a positive impact on teacher performance, so it is clear that leadership carried out by a principal has a profound impact on the performance of teachers who are in charge.

\section{The working group of teachers toward influence teacher performance}

Based on testing working group variable significance toward teacher performance obtained value $_{\text {for }}$ the variable teacher working group activities amounted $3.903>\mathrm{t}_{\text {table }} 2.009$. Based on this, it is concluded that the alternative hypothesis is accepted, which means that teacher work group activities have a positive and significant effect on teacher performance in state of elementary school in cluster 3, Kayuagung District. To confirm these results, it can also be seen that the significance value is $0.000<0.05$, which means that the alternative hypothesis $\left(\mathrm{H}_{\mathrm{a}}\right)$ is accepted and the statistical hypothesis $\left(\mathrm{H}_{0}\right)$ is rejected.

The correlation coefficient or the magnitude of the relationship between teacher work group activities and teacher performance is $48.7 \%$. The magnitude of the relationship is in a fairly close category. The determinant coefficient or the magnitude of the influence of the variable teacher work group activities on the performance of teachers in state of elementary school in cluster 3, Kayuagung District, is $23.7 \%$ and is included in the low influence category.

From the results of this study there is a similarity with previous research, namely research Saroh\&Latifah conducted research in 2014, with the title of research, namely the influence of principal leadership and teacher activeness in participating in MGMP on teacher performance, namely working group activities have a positive and significant effect on teacher performance [14]

Apart from the leadership factor of the Principal, teacher performance is also influenced by the activeness of teachers in participating in Teacher Working Group (KKG) activities. Many problems faced by teachers can be discussed and resolved through this forum. The participation of teachers in participating in the various activities held by the KKGwill also be able to improve teacher performance.

\section{The influence of principal leadership and teacher work group activities on teacher performance}

The achievement of the most research respondents' final score regarding teacher performance is found at a value of 80.91 . This value was achieved by 11 (eleven) research respondents. The teacher's performance is very good, only 2 (two) people. This means that most respondents stated that the teacher's performance was categorized as good. The highest value achieved by research respondents related to teacher performance is 86.36 and the smallest value obtained by research respondents is 74.55. In general, the teacher's performance was stated to be good.

If the analysis is carried out based on the classification of the sample group, the highest final average value is achieved by state of elementary school 8 Kayuagung of 81.64. The lowest final average value is found in state of elementary school 5 Kayuagung amounting to 80.52. If an in-depth analysis is carried out, that the difference between the highest and lowest values is not so wide, namely 1.12 . This value is not declared significant because the highest and lowest scores are still in the same category, namely the teacher's performance is good.

Simultaneous hypothesis testing obtained aFvalue $_{\text {calculated }}$ of $12.383>\mathrm{F}_{\text {Table }}$ of 3.191 , which means that there is a positive and significant influence on the leadership of the principal and the activities of the teacher working group together on the performance of teachers in state of elementary school in cluster 3, Kayuagung District. To emphasize, it can also be seen from the significance value obtained, namely 0.000 $<0.05$, which means that the alternative hypothesis $\left(\mathrm{H}_{\mathrm{a}}\right)$ is accepted and the statistical hypothesis $\left(\mathrm{H}_{0}\right)$ is rejected.

There is a relationship between the principal's leadership and teacher working group activities with the performance of teachers in state of elementary school in cluster 3, Kayuagung District, of 0.583 or $58.3 \%$, thus it is categorized as a fairly close or quite high relationship. The leadership of the principal and the activities of the teacher working group jointly affected the performance of teachers in state of elementary school in cluster 3, Kayuagung District by $34.0 \%$ and was included in the low influence category.

Apart from the leadership factor of the Principal, teacher performance is also influenced by the activeness of teachers in participating in Teacher Working Group (KKG) activities.

Many problems faced by teachers can be discussed and resolved through this forum. The participation of teachers in participating in various activities held by the KKG were also be able to improve teacher performance

\section{CONCLUSION}

From the studies that have been conducted by researchers on research variables, as well as analyzing the findings in the research, it can be concluded that the following matters can be made: namely the leadership of the principal has a positive and significant influence on the performance of teachers in SD Negeri in cluster 3, Kayuagung District. value $_{\mathrm{T}}$ obtained from the test are $4.967>\mathrm{t}_{\text {table }}$ is 2.009 . The magnitude of the influence of the principal's leadership variable on the performance of SD Negeri teachers in cluster 3, Kayuagung District, is $33.5 \%$ and is included in the low influence category. The teacher work group has a positive and significant effect on the performance of teachers in state of elementary school in cluster 3, Kayuagung District. Value of $t_{\text {count }}>t_{\text {Table }} ; 3,903>2,009$ which means acceptance of the alternative hypothesis. The magnitude of the influence of the teacher working group variable on the performance of teachers in SD Negeri in cluster 3, Kayuagung District is $23.7 \%$ and is in the low category. There is a positive and significant influence on the leadership of the principal and the activities of 
the teacher work group together on teacher performance in state of elementary school in cluster 3 of Kayuagung District. The $\mathrm{F}$ value calculated obtained from testing is 12.383 $>\mathrm{F}_{\text {Table }}$ of 3.191. The amount of influence simultaneously is $34.0 \%$ and is included in the low influence category.

\section{REFERENCES}

[1] Komalasari, Y. Arafat, and Mulyadi, "Principal's Management Competencies in Improving the Quality of Education," J. Soc. Work Sci. Educ. Vol., vol. 1, no. 2, pp. 181-193, 2020.

[2] H. Irmayani, D. Wardiah, and M. Kristiawan., "The strategy of SD Pusri in improving educational quality," Int. J. Sci. Technol. Res., vol. 7, no. 7, pp. 113-121, 2018.

[3] R. Abdullah, "Pembelajaran dalam perspektif kreativitas guru dalam pemanfaatan media pembelajaran," Lantanida J., vol. 4, no. 1, p. 35, Sep. 2017.

[4] A. K. A. Ahmad Sahidah, "Attractive: Innovative Education Journal," Innov. Educ. J., vol. 2, no. 2, pp. 1-13, 2020.

[5] B. Isdaryanti, M. Rachman, Y. L. Sukestiyarno, T. S. Florentinus, and W. Widodo, "Teachers' performance in science learning management integrated with character education," J. Pendidik. IPA Indones., vol. 7, no. 1, pp. 9-15, 2018.

[6] K. Pyhalto, J. Pietarinen, and T. Soini, "Teachers professional agency and learning-from adaption to active modification in the teacher community," Teach. Teach. Theory Pract., vol. 21, no. 7, pp. 811-830, 2015.

[7] I. Hidayah and Sugiarto, "Model of Independent Working Group of Teacher and its Effectiveness towards the Elementary School Teacher's Ability in Conducting Mathematics Learning," Procedia - Soc. Behav. Sci., vol. 214, no. June, pp. 43-50, 2015.

[8] L. H. Winingsih, I. Agung, and A. A. Sulistiono, "The influence of government policy, principle leadership, and participation of parents on strengthening teacher organizations (KKG/MGMP) and development of problem solving in students: Indonesia case," Int. J. Educ. Pract., vol. 7, no. 4, pp. 479-493, 2019.

[9] D. Purwana, A. Ahmad, and A. Saptono, "The Influence of Leadership and Work Environment toward Organziational Citizenship Behavior (OCB) through Work Satisfaction," Int. J. Adv. Sci. Educ. Relig., vol. 3, no. 2, pp. 57-71, 2020.

[10] L. Li, P. Hallinger, and A. Walker, "Exploring the mediating effects of trust on principal leadership and teacher professional learning in Hong Kong primary schools," Educ. Manag. Adm. Leadersh., vol. 44, no. 1, pp. 20-42, 2016.

[11] \& M. Rahmayani, D., Arafat, Y., "The Effect of Principal Leadership Behavior and Community Participation on the Implementation of Education in SMP Negeri 11 Prabumulih," J. Sch. Leadersh. Manag., vol. 5, no. 2, 2020.

[12] S. Damayanti T., Arafat, Y., Eddy, "The Effect of Principal Leadership and Work Motivation on
Teacher Performance. Media," Media, vol. 1, no. $1,2020$.

[13] E. B. Kozleski, "The uses of qualitative research: Powerful methods to inform evidence-based practice in education.," Res. Pract. Pers. with Sev. Disabil., vol. 42, no. 1, pp. 19-32., 2017.

[14] L. Saroh, I., \& Latifah, "The influence of principal leadership and teacher activeness in participating in MGMP on teacher performance," J. Educ. Dyn. Educ. Econ., vol. IX, no. 1, pp. 41-47., 2014.

[15] M. Nova, Rohana, and M. Kristiawan, "The Effect of Certified Teachers and Principal Leadership toward Teachers' Performance," Int. J. Educ. Rev., vol. 1, no. 2, pp. 1-8, 2019. 